\title{
Five new species of Sepsidae (Diptera) from Ethiopia and Kenya
}

\section{Пять новых видов мух-муравьевидок (Diptera, Sepsidae) из Эфиопии и Кении}

\author{
A.L. Ozerov

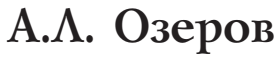 \\ Zoological Museum, Moscow Lomonosov State University, Bol'shaya Nikitskaya 6, Moscow 125009, Russia. E-mail: \\ ozerov2455@ rambler.ru \\ Зоологический музей, Московский государственный университет им. М.В. Ломоносова, Большая Никитская ул., 6, Москва \\ 125009 , Россия.
}

KEY WORDS: Diptera, Sepsidae, Adriapontia, Afrosepsis, Meroplius, Sepsis, new species, Afrotropical Region, Ethiopia, Kenya.

КЛЮЧЕВЫЕ СЛОВА: Diptera, Sepsidae, Adriapontia, Afrosepsis, Meroplius, Sepsis, новые виды, Афротропическая область, Кения, Эфиопия.

ABSTRACT. Five new species of Sepsidae Adriapontia dmitrii sp.n. from Kenya, Adriapontia medvedevi sp.n., Afrosepsis elenae sp.n., Meroplius vikhrevi sp.n. and Sepsis amharaica sp.n. from Ethiopia are described. Adriapontia aethiopica Ozerov, 2000 is redescribed. Key to species of the genus Adriapontia is given.

РЕЗЮМЕ. Пять новых видов из семейства Sepsidae описаны: Adriapontia dmitrii sp.n. из Кении, Adriapontia medvedevi sp.n., Afrosepsis elenae sp.n., Meroplius vikhrevi sp.n. и Sepsis amharaica sp.n. из Эфиопии. Adriapontia aethiopica Ozerov, 2000 переописан. Приведена таблица для определения видов рода Adriapontia.

\section{Introduction}

Sepsidae is a small, morphologically uniform family of acalyptrate flies in the superfamily Sciomyzoidea, occuring in all zoogeographical regions of the world, except Antarctic. The world fauna currently comprises almost 350 species, and more than 120 species belonging to 18 genera of them occur in the Afrotropical Region [Ozerov, 2005, 2006, 2010, 2011].

New material of Sepsidae collected in Ethiopia and Kenya during field trips organized by Dr. Nikita Vikhrev (Moscow) enriched the collection of the Zoological Museum, Moscow University (ZMUM). During the determination of this material five new to science species were discovered. Their descriptions are given below.

Terminology follows McAlpine [1981], Cumming et al [2009], and Stuckenberg [1999].

The following abbreviations are used for depositories of the studied specimens: BMNH — The Natural
History Museum [formerly British Museum (Natural History)], London, United Kingdom; TAU — Tel Aviv University, Tel Aviv, Israel; ZMUM - Zoological Museum, Moscow State University, Russia.

Other abbreviations used: $a-$ anterior; $d-$ dorsal; $p$ - posterior; $v$ - ventral, and combinations of these latter four, all used for leg chaetotaxy.

\section{Taxonomic part}

Genus Adriapontia Ozerov, 1996.

Adriapontia Ozerov, 1996: 139. Gender: feminine. Type-species: Sepsis capensis Hennig, 1960, by original designation.

A genus endemic to the Afrotropical Region comprises 6 described species [Ozerov, 2005]. The genus was revised and a key to species provided by Ozerov [2000]. Descriptions of 2 new species are given below. Besides the redescription of Adriapontia aethiopica Ozerov, 2000 is given. I noted in the original description [Ozerov, 2000: 274] presence of one pair of dorsocentral setae incorrectly. A new key to species of Adriapontia is provided below.

Adriapontia aethiopica Ozerov, 2000 Figs 1-5.

MATERIAL. "C. Abyssinia: Managascha, 3000 m, 18.V.1914, O. Kovacs, B.M. 1923-306" (paratype 9 , in NHML); ETHIOPIA: Oromya, Debr Libanos $\left(9.732^{\circ} \mathrm{N} 38.816^{\circ} \mathrm{E}\right), 2500 \mathrm{~m}, 29-30$.VII. 2012, coll. N. Vikhrev (5 $0^{7} \sigma^{7}, 2$ 9 , in ZMUM); ETHIOPIA: Shewa, Menagesha Forest $\left(9.033^{\circ} \mathrm{N} 38.583^{\circ} \mathrm{E}\right), 3050 \mathrm{~m}, 11 . \mathrm{X} .2005$, coll. A. Freidberg (1 $0^{7}$, in TAU).

DESCRIPTION. Length of body: $4.4-5.0 \mathrm{~mm}$. Length of wing: $3.7-4.7 \mathrm{~mm}$.

Male. Head (Fig. 1), eye in lateral view roundish. Frons black, with a violet tinge, subshining. Face and 

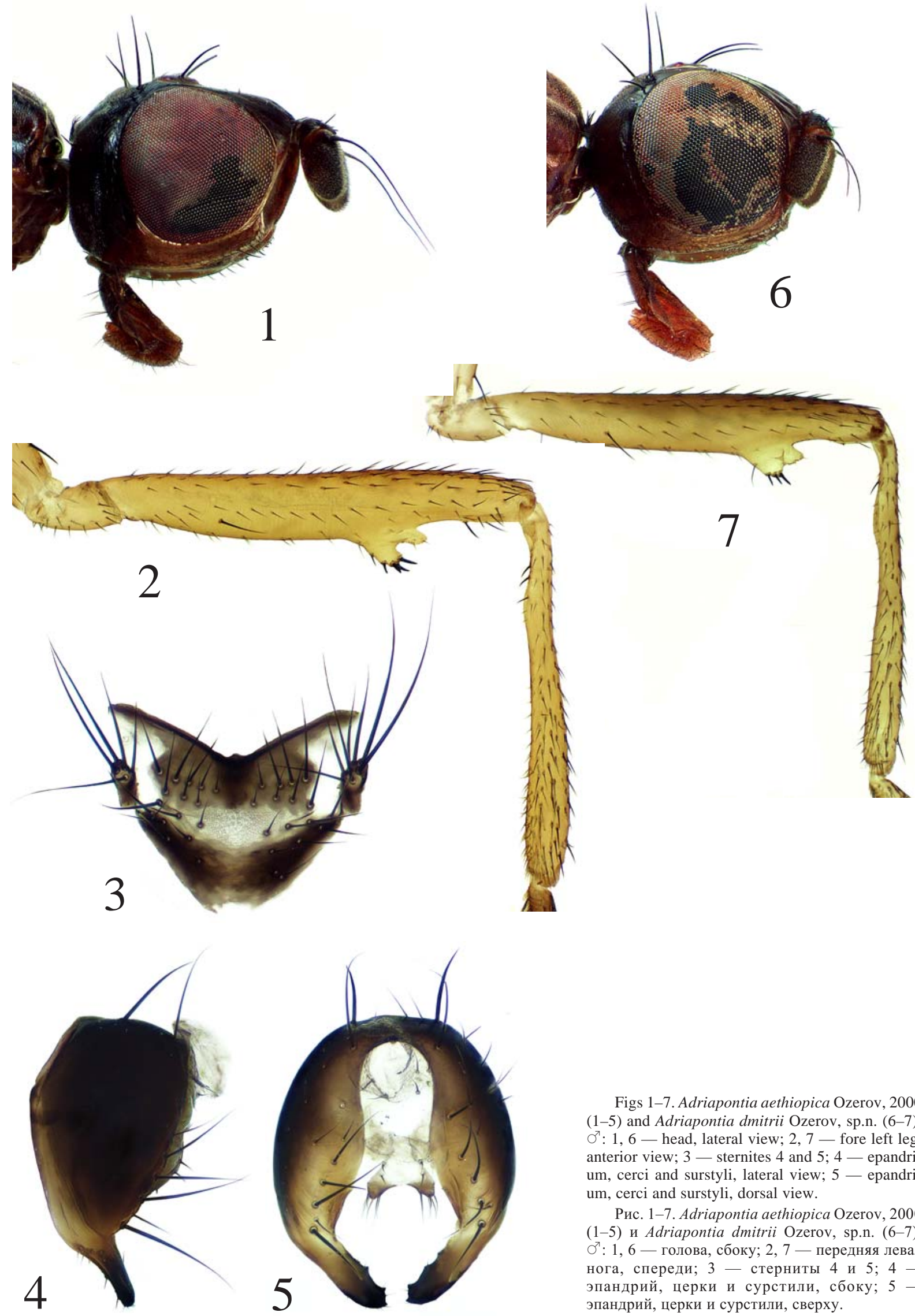

Figs 1-7. Adriapontia aethiopica Ozerov, 2000 (1-5) and Adriapontia dmitrii Ozerov, sp.n. (6-7), $0^{7}: 1,6$ - head, lateral view; 2,7 - fore left leg, anterior view; 3 - sternites 4 and 5; 4 - epandrium, cerci and surstyli, lateral view; 5 - epandrium, cerci and surstyli, dorsal view.

Рис. 1-7. Adriapontia aethiopica Ozerov, 2000 (1-5) и Adriapontia dmitrii Ozerov, sp.n. (6-7), $0^{7}: 1,6$ - голова, сбоку; 2, 7 - передняя левая нога, спереди; 3 - стерниты 4 и $5 ; 4-$ эпандрий, церки и сурстили, сбоку; 5 эпандрий, церки и сурстили, сверху. 
gena brown to dark brown; face whitish microtrichose. Height of gena below eye approximately $1 / 7$ times as long as vertical diameter of eye (Fig. 1). Clypeus black. Postcranium black, greyish microtrichose; lateral occipital sclerite with several setulae. 1 ocellar, 1 divergent postocellar, 1 inner vertical, 1 outer vertical setae present. Gena with a row of setulae along lower margin. Strong vibrissae not developed, only 2-3 short subvibrissae. Postgena without a seta near lower margin. Antenna blackish, but postpedicel reddish brownish inside. Postpedicel in profile long-oval, approximately 2 times longer than wide, roundish apically.

Thorax black completely or postpronotum, proepisternum, proepimeron and anterior part of anepisternum reddish brown. Scutum greyish microtrichose; 2 notopleural (anterior short), 0+1 supra-alar, 1 postalar setae present; dorsocentral and postpronotal setae absent. Proepisternum shining, but along lower margin whitish microtrichose. Proepimeron shining in upper half and whitish microtrichose in lower half. Anepisternum shining, with 1 long seta near posterior margin. Katepisternum extensively silvery-greyish microtrichose. Anepimeron shining, but with narrow greyish stripe along posterior margin; pleural wing process shining, but greater ampulla greyish microtrichose. Meron, katepimeron, metepisternum, metepimeron and anatergite greyish microtrichose. Katatergite greyish microtrichose, but with shining spot in centre. Mediotergite shining, but microtrichose on border with anatergite. Postmetacoxal bridge present. Scutellum and subscutellum greyish microtrichose. Scutellum with pair of well-developed apical setae and pair of basal setulae.

Legs. Legs yellow in ground colour, but mid and hind femora in apical half or third, mid tibia basally and hind tibia darkened. Coxa of foreleg long and simple, with preapical $d$. Fore femur and tibia as in Fig. 2. Coxa of midleg bare in upper half. Femur of midleg with a row of short $a$, of which one in apical third stronger. Tibia of midleg with $1 a v$ in apical third, with $1-2$ short $p$, with 1 preapical $d$, with 1 strong apical $p v$ and 3-5 apical $a v$ setae. Femur of hindleg with 1 strong $a d$ in apical quarter. Tibia of hindleg without osmeterium or osmeterium-like area anterodorsally, with $1 a$ at middle, with 1 preapical $d$ and with 1 apical $a$ setae.

Wing longer than abdomen, with moderate anal lobe. Calypters and their margins blackish. Halter yellowish. Cells $b m$ and $b r$ separate. Alula entirely covered with microtrichia. Margin of upper calypter with hairs, margin of lower calypter without hairs.

Abdomen black, shining, slightly constricted after syntergite $1+2$. Tergites $1-5$ each covered with setulae, strong setae absent. Sternites 4 and 5 as in Fig. 3. Surstyli symmetrical, fused to epandrium (Figs 4-5).

Female. Resembles male. Femur and tibia of foreleg simple.Tibia of midleg with $0-1 p v$ at middle. Femur of hindleg without $a d$.

COMPARISON. This species is distinguished from congerens by the absence of the dorsocentral setae.

DISTRIBUTION. Kenya.

\section{Adriapontia dmitrii Ozerov, sp.n.}

Figs 6, 7.

MATERIAL. Holotype $\sigma^{7}$, labelled "KENYA: Kiambu Co., 3 $\mathrm{km}$ NE Kijabe $\left(0.93192^{\circ} \mathrm{S} 36.61637^{\circ} \mathrm{E}\right), 2599 \mathrm{~m}, 18 . \mathrm{XII} .2013$, coll. D.Gavryushin" (in ZMUM). Paratype: $\sigma^{7}$, labelled "KENYA: Kiambu Co., $\left(0.932^{\circ} \mathrm{S} 36.616^{\circ} \mathrm{E}\right), 2600 \mathrm{~m}, 18 . X I I .2013$, coll. N.Vikhrev" (in ZMUM).

DESCRIPTION. Male. Head and eye in lateral view roundish (Fig. 6). Frons dark brown, subshining. Face and gena brownish; face whitish microtrichose. Height of gena below eye approximately 1/10 times as long as vertical diameter of eye (Fig. 6). Clypeus black. Postcranium black, greyish microtrichose; lateral occipital sclerite with several setulae. 1 ocellar, 1 divergent postocellar, 1 inner vertical, 1 outer vertical setae present. Gena with a row of setulae along lower margin. 2-3 very thin and short vibrissae. Postgena with a seta near lower margin. Antenna blackish, but postpedicel reddish brown inside. Postpedicel in profile long-oval, approximately 1.5 times longer than wide, roundish apically.

Thorax black, but pleura reddish brown. Scutum, including postpronotal lobe, greyish microtrichose; 1 (posterior) notopleural, $0+1$ supra-alar, 1 postalar, $0+1$ dorsocentral setae present; postpronotal setae absent. Proepisternum shining, but along lower and upper margins whitish microtrichose. Proepimeron shining in upper half and whitish microtrichose in lower half. Anepisternum shining, with 1 long seta near posterior margin. Katepisternum extensively silvery-greyish microtrichose. Anepimeron shining, but with narrow greyish stripe along posterior margin; pleural wing process greyish microtrichose. Meron, katepimeron, metepisternum, metepimeron, katatergite and anatergite greyish microtrichose. Mediotergite shining, but microtrichose on border with anatergite. Postmetacoxal bridge present. Scutellum and subscutellum greyish microtrichose. Scutellum with well-developed apical setae; basal setae short, hair-like.

Legs. Legs yellow in ground colour, but mid and hind femora in apical half or third and hind tibia darkened. Coxa of foreleg long and simple, without preapical $d$. Fore femur and tibia as in Fig. 7. Coxa of midleg bare in upper half. Femur of midleg with a row of short $a$, of which one in apical third stronger. Tibia of midleg with $1 v$ in apical third, with $1-2 p$ in apical half, with 1 preapical $d$, with 2 apical $p v$ and 3-5 apical $a v$ setae. Femur of hindleg with 1 long ad in apical quarter. Tibia of hindleg without osmeterium or osmeteriumlike area anterodorsally, with $1 a$ at middle, with 1 preapical $d$ and with 1 apical $a$ setae.

Wing tinged with brownish, longer than abdomen, with moderate anal lobe. Calypters and their margins blackish. Halter yellowish. Cells $b m$ and $b r$ separate. Alula entirely covered with microtrichia. Margin of upper calypter with hairs, margin of lower calypter without hairs.

Abdomen black, shining, slightly constricted after syntergite $1+2$. Tergites $1-5$ each covered with setulae, strong setae absent. Surstyli symmetrical, fused to epandrium. 
Length of body: 4.4-4.5 mm. Length of wing: 4.0$4.2 \mathrm{~mm}$.

Female unknown.

COMPARISON. Both species, Adriapontia dmitrii and the other, A. medvedevi (see below), is distinguished from congerens by absence of postpronotal seta and presence of one pair of dorsocentral setae. Male of Adriapontia dmitrii has simple tibia of hindleg, while male hind tibia of $A$. medvedevi posteriorly with two long hairs apically.

ETYMOLOGY. The species is named after Mr. Dmitri I. Gavryushin, curator of Limoniidae in ZMUM, and the collector of the holotype specimen.

DISTRIBUTION. Kenya.

\section{Adriapontia medvedevi Ozerov, sp.n.} Figs 8-12.

MATERIAL. Holotype $\sigma^{\prime}$, labelled "ETHIOPIA: Oromya, Debr Libanos $\left(9.732^{\circ} \mathrm{N} 38.816^{\circ} \mathrm{E}\right), 2500 \mathrm{~m}, 29-30$. VII.2012, coll. N Vikhrev" (in ZMUM).

DESCRIPTION. Male. Head and eye in lateral view roundish. Frons black, with a violet tinge, shining. Face and gena brownish; face whitish microtrichose. Height of gena below eye approximately 1/10 times as long as vertical diameter of eye. Clypeus black. Postcranium dark brown, greyish microtrichose; lateral occipital sclerite with several setulae. 1 ocellar, 1 divergent postocellar, 1 inner vertical, 1 outer vertical setae present. Gena with a row of setulae along lower margin. Strong vibrissae not developed, only 2-3 short subvibrissae. Postgena without a seta near lower margin. Antenna brownish, but postpedicel blackish anteriorly. Postpedicel in profile longoval, approximately 1.5 times longer than wide, roundish apically.

Thorax black, but postpronotum, proepisternum, proepimeron and anterior part of anepisternum reddish brown. Scutum greyish microtrichose; 1 (posterior) notopleural, 0+1 supra-alar, 1 postalar, 0+1 dorsocentral setae present; postpronotal setae absent. Proepisternum shining, but along lower and upper margins whitish microtrichose. Proepimeron shining in upper half and whitish microtrichose in lower half. Anepisternum shining, with 1 long seta near posterior margin. Katepisternum extensively silvery-greyish microtrichose. Anepimeron shining, but with narrow greyish stripe along posterior margin; pleural wing process greyish microtrichose. Meron, katepimeron, metepisternum, metepimeron, katatergite and anatergite greyish microtrichose. Mediotergite shining, but microtrichose on border with anatergite. Postmetacoxal bridge present. Scutellum and subscutellum greyish microtrichose. Scutellum with well-developed apical setae; basal setae short, hair-like.

Legs. Legs yellow in ground colour, but mid and hind femora in apical half with dark ring, mid and hind tibia darkened basally; tarsi of all legs blackish. Coxa of foreleg long and simple, with preapical $d$. Fore femur and tibia as in Fig. 8. Coxa of midleg bare in upper half. Femur of midleg with a row of short $a$. Tibia of midleg with $1 v$ in apical third, with 1 preapical $d$, with 2 long apical $p$ and 3-5 apical $a v$ setae. Femur of hindleg with 1 long $a$ in apical quarter. Tibia of hindleg without osmeterium or osmeterium-like area anterodorsally, with $1 a$ at middle, with 1 preapical $d$, and with long $1 a v$ and $1 v$ hairs apically (Fig. 9).

Wing tinged with brownish, longer than abdomen, with moderate anal lobe. Calypters and their margins blackish. Halter yellowish. Cells $b m$ and $b r$ separate. Alula entirely covered with microtrichia. Margin of upper calypter with hairs, margin of lower calypter without hairs.

Abdomen black, shining, slightly constricted after syntergite $1+2$. Tergites $1-5$ each covered with setulae, strong setae absent. Sternites 4 and 5 as in Fig. 10. Surstyli symmetrical, fused to epandrium (Figs 11, 12).

Length of body: $4.1 \mathrm{~mm}$. Length of wing: $3.4 \mathrm{~mm}$. Female unknown.

COMPARISON. The new species is similar to $A$. dmitrii (see above), but hind tibia of male posteriorly with two long hairs apically (Fig. 9).

ETYMOLOGY. The species is named after Mr. Andrey F. Medvedev, curator of Odonata, Ephemeroptera and some others in ZMUM, in recognition of his contribution to regulation in these orders.

DISTRIBUTION. Ethiopia.

\section{Key to species of ADRIAPONTIA OZerov}

1. Scutum with dorsocentral setae present ....................... 2

- Scutum with dorsocentral setae absent ..... A. aethiopica Ozerov

2. Scutum with 2 dorsocentral setae. Femur and tibia of foreleg: see Ozerov, 2000: Fig. 1. 1-4 ..... A. capensis (Hennig)

- Scutum with 1 dorsocentral seta .................................... 3

3. Scutum with postpronotal seta absent ............................. 4

- Scutum with postpronotal seta present ……………..... 5

4. Tibia of hindleg of male posteriorly with two long hairs apically (Fig. 9). Femur and tibia of foreleg as in Fig. 8 A. medvedevi sp.n.

- Tibia of hindleg of male posteriorly without long hairs apically. Femur and tibia of foreleg as in Fig. 7 ............

A. dmitrii sp.n.

5. $\mathrm{\sigma}^{\mathrm{T}}$ : Tibia of midleg with 2-6 long hairs posteriorly in apical third (Fig. 7. 5)

- $\sigma^{2}$ : tibia of midleg with 3-4 short setae posteriorly in apical quarter

6. Hind coxa ventrally with strong seta. Femur and tibia of foreleg see Ozerov, 2000: Fig. 7. 1-4 .

A. ugandica Ozerov

- Hind coxa ventrally with hair. Femur and tibia of foreleg see Ozerov, 2000: Fig. 2. 1-4

A. ihongeroensis (Vanschuytbroeck)

7. Femur and tibia of foreleg see Ozerov, 2000: Fig. 5. 1-4 A. freidbergi Ozerov

- Femur and tibia of foreleg see Ozerov, 2000: Fig. 6. 1-4 A. tanzanica Ozerov

- Femur and tibia of foreleg see Ozerov, 2000: Fig. 3. 1-4 A. kyanyamaensis (Vanschuytbroeck) 

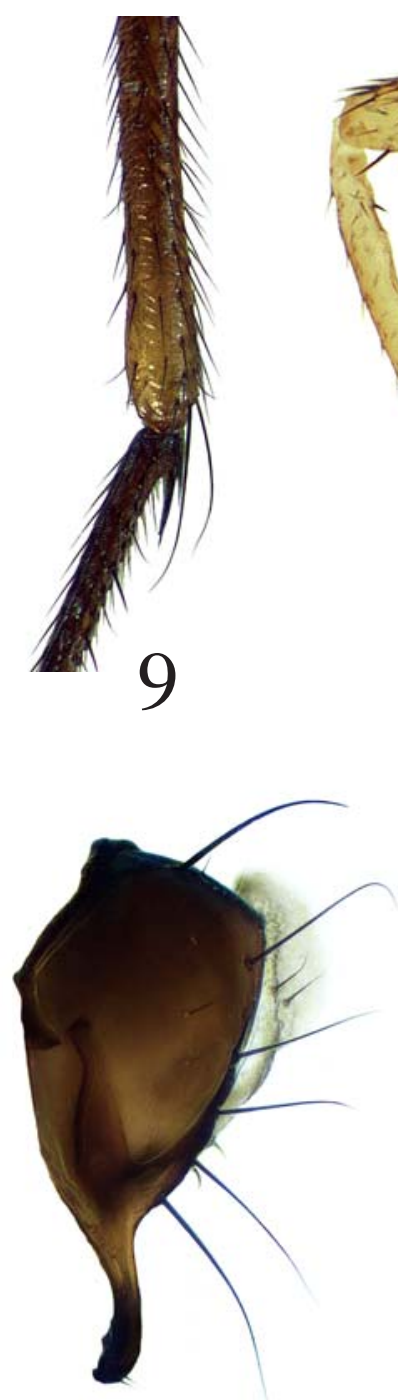

11

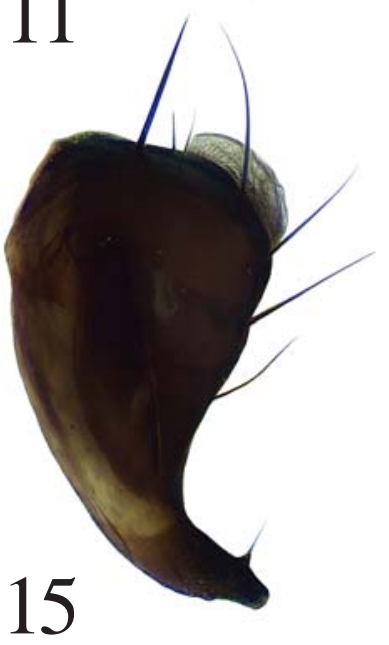

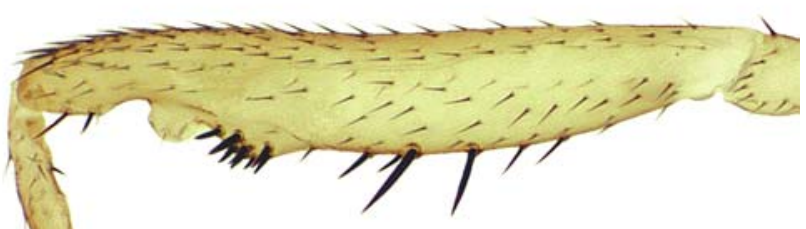
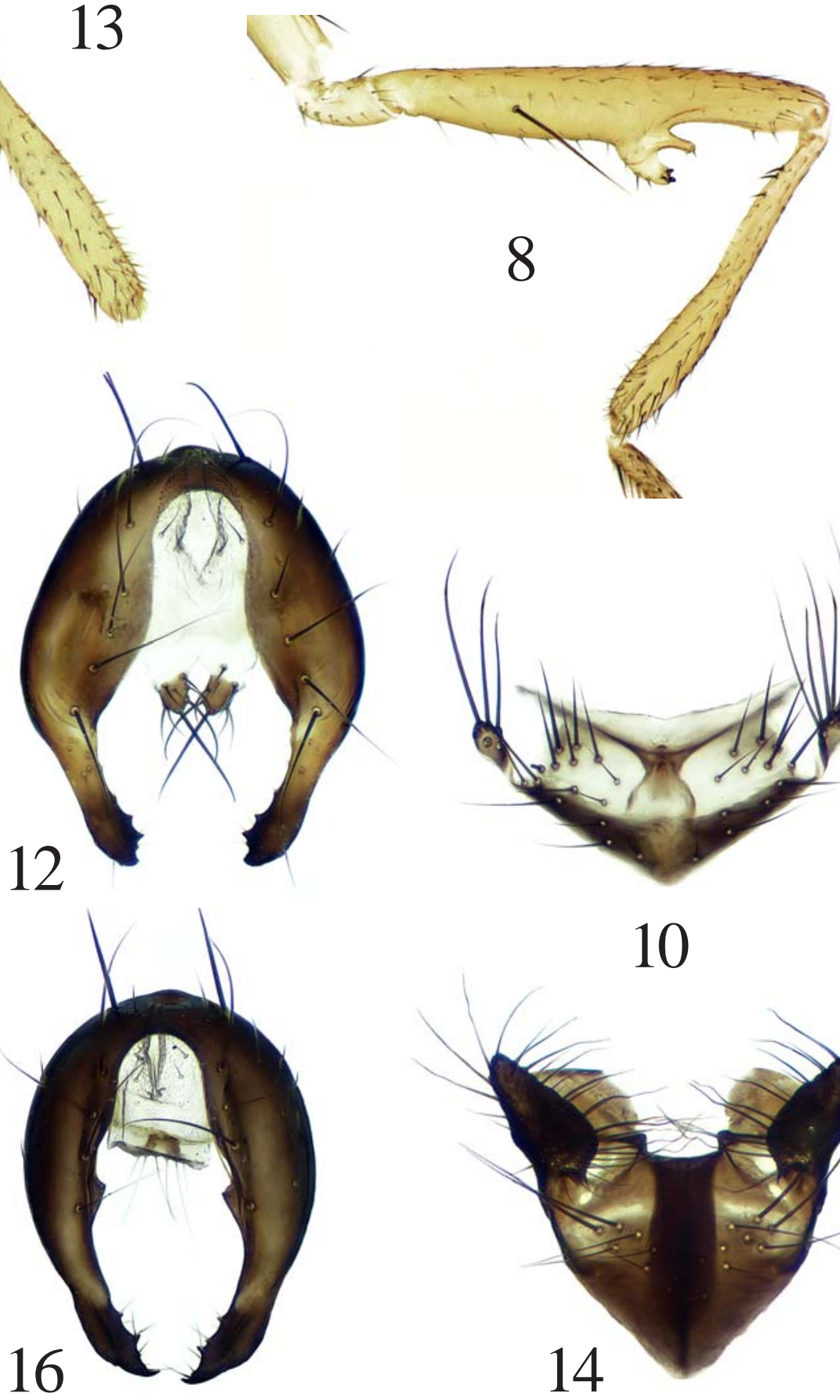

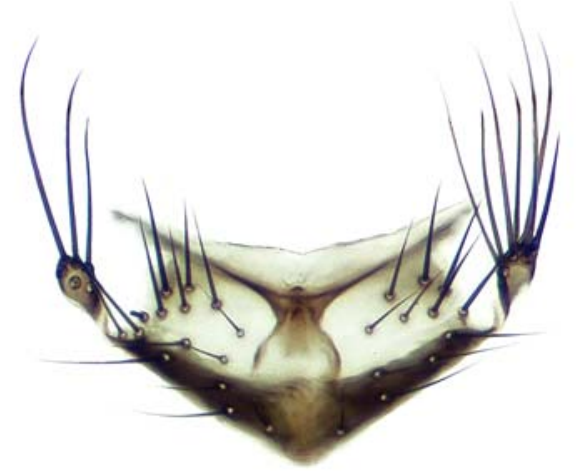

10

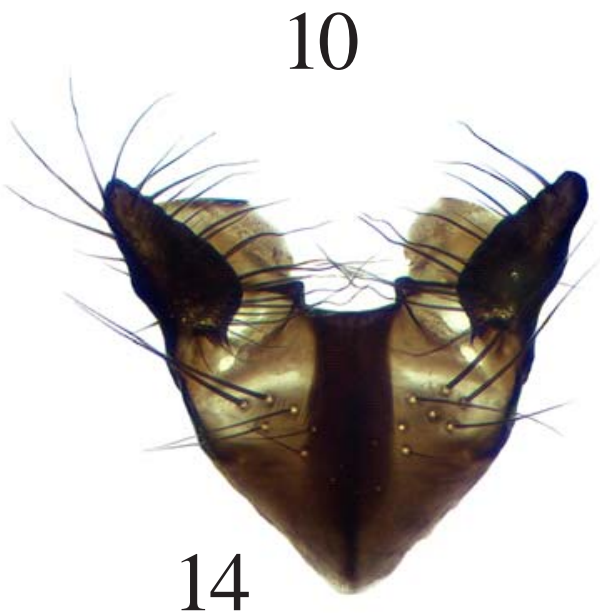

Figs 8-16. Adriapontia medvedevi Ozerov, sp.n. (8-12) and Afrosepsis elenae Ozerov, sp.n. (13-16), $\sigma^{7}$ holotype: $8-$ fore left leg, anterior view; 9 - apical part of hind tibia, anterior view; $10,14-$ sternites 4 and 5; 11, 15 — epandrium, cerci and surstyli, lateral view; 12, 16 - epandrium, cerci and surstyli, dorsal view; 13 - fore left leg, posterior view.

Рис. 8-16. Adriapontia medvedevi Ozerov, sp.n. (8-12) and Afrosepsis elenae Ozerov, sp.n. (13-16), О7 голотип: 8- передняя левая нога, спереди; 9 - апикальная часть задней голени, спереди; 10, 14 - стерниты 4 и $5 ; 11,15$ - эпандрий, церки и сурстили, сбоку; 12, 16 - эпандрий, церки и сурстили, сверху; 13 - передняя левая нога, сзади. 


\section{Genus Afrosepsis Ozerov, 1996}

Afrosepsis Ozerov, 1996: 141. Gender: feminine. Type-species: Afrosepsis camerounica Ozerov, 1996: 142, by original designation.

A genus endemic to the Afrotropical Region with 5 described species, recorded collectively from Angola, Cameroon, Tanzania and Uganda [Ozerov, 2005]. The genus was revised and a key to species provided by Ozerov [1999a]. Description of a new species from Ethiopia is given below.

\section{Afrosepsis elenae Ozerov, sp.n.} Figs 13-16.

MATERIAL. Holotypus $\sigma^{7}$, labelled "ETHIOPIA: Amhara, Blue Nile $\left(10.08^{\circ} \mathrm{N} 38.19^{\circ} \mathrm{E}\right), 1700 \mathrm{~m}, 31$. VII.2012, coll. N. Vikhrev" (in ZMUM).

DESCRIPTION. Male. Head. Frons black, shining. Face and antennal grooves blackish, matt. Face narrow; postpedicel wider than distance between eyes at level of vibrissae. Gena very narrow (linear), brown. Postcranium black, greyish microtrichose. 1 ocellar, 1 divergent postocellar, 1 inner vertical, 1 outer vertical setae present. Postpedicel in profile long-oval, with roundish apex, approximately 1.5 times as long as wide. Postgena with a seta in lower part. 3 very short vibrissae.

Thorax. Scutum greyish microtrichose, but shining from the outside of lines of dorsocental setae; 1 postpronotal, 2 notopleural, 1 supra-alar, $0+2$ dorsocentral setae present. Proepisternum and proepimeron greyish microtrichose. Anepisternum shining, but with narrow greyish stripe along posterior margin. Katepisternum silvery-greyish microtrichose, but with a big shining spot in anterior half. Anepimeron shining, but narrowly greyish microtrichose along posterior margin; pleural wing process greyish microtrichose. Meron, katepimeron, metepisternum, metepimeron, katatergite and anatergite extensively greyish microtrichose. Mediotergite shining, but greyish microtrichose along lateral margins. Scutellum greyish microtrichose.

Legs. Fore femur and tibia yellow. Mid and hind femora black at middle, but yellow basally and apically. Mid tibia in basal half black, but yellow in apical half. Hind tibia black, but yellowish in apical quarter. All tarsomeres 1-3 yellow, all tarsomeres 4 and 5 blackish. Fore femur and tibia as in Fig. 13; fore femur without $a v$ basally. Mid coxa bare. Mid tibia without setae, except 3 apical $a v$. Hind tibia with short preapical $d$.

Wing clear, blackish only in basal costal cell and basal half of costal cell; veins brown. Calypters yellowish; margin of upper calypter yellowish, margin of lower calypter darkened. Halter yellowish. Alula narrow, entirely covered with microtrichia.

Abdomen. Syntergite $1+2$ at sides with several setulae. Tergites 3-5 each with two median marginal setae. Sternites 4 and 5 as in Fig. 14. Epandrium and surstyli as in Figs 15, 16.

Body length $3.2 \mathrm{~mm}$; wing length $2.6 \mathrm{~mm}$.

Female unknown.
COMPARISON. The new species is closely related to A. sublateralis Vanschuytbroeck, 1962. Scutum of Afrosepsis elenae is greyish microtrichose before transverse suture while the scutum of $A$. sublateralis is shining; also differences are present in a structure of surstyli.

ETYMOLOGY. The species is named after Mrs. Elena A. Erofeeva, volunteer, in recognition of her valuable contributions to improvement of the state of Diptera and Orthoptera collections in ZMUM.

DISTRIBUTION. Ethiopia.

\section{Genus Meroplius Rondani, 1874}

Meroplius Rondani, 1874: 175. Gender: masculine. Type-species: Nemopoda stercoraria Robineau-Desvoidy, 1830 [= Sepsis minuta Wiedemann, 1830], by original designation.

Protomeroplius Ozerov, 1999b: 92 [described as a subgenus of Meroplius]. Gender: masculine. Type-species: Meroplius trispinifer Ozerov, 1999, by original designation.

A genus of 22 described species worldwide, 12 of which are recorded from the Afrotropical Region [Ozerov, 2005]. Afrotropical species of Meroplius were revised and a key to 8 species provided by Ozerov [1999b]. 4 additional Afrotropical species was described by Ozerov [2004, 2011]. Description of a new species from Ethiopia is given below.

\section{Meroplius vikhrevi Ozerov, sp.n.} Figs 17-20.

MATERIAL. Holotype $\sigma^{\prime}$, labelled "ETHIOPIA: Oromya, Debr Libanos $\left(9.732^{\circ} \mathrm{N} 38.816^{\circ} \mathrm{E}\right), 2500 \mathrm{~m}, 29-30 . \mathrm{VII} .2012$, coll. N. Vikhrev" (in ZMUM). The holotype is pinned. Abdomen and right foreleg dissected and stored in glycerine in microvial pinned with the holotype.

DESCRIPTION. MALE. Head in lateral view slightly flattened dorsoventrally. Eye in lateral view roundish. Frons black, subshining. Facial carina and gena brown; antennal grooves blackish. Height of gena below eye approximately $1 / 6$ times as long as vertical diameter of eye. Clypeus black. Postcranium black, greyish microtrichose. 1 orbital, 1 ocellar, 1 divergent postocellar, 1 inner vertical, 1 outer vertical setae present. Postredicel in profile oval, slightly longer than wide. 1 vibrissa. Antenna brown, but postredicel darkened from outside.

Thorax Thorax black. Scutum grey microtrichose; 1 postpronotal, 2 notopleural, $0+1$ supra-alar, 1 postalar, $0+1$ dorsocentral setae present. Proepisternum greyish microtrichose. Proepimeron shining, but along lower margin greyish microtrichose. Anepisternum shining. Katepisternum shining, with greyish microtrichose stripe along upper margin. Anepimeron shining, but narrowly greyish microtrichose along posterior margin; pleural wing process shining. Katepimeron shining. Meron, metepisternum, metepimeron, katatergite and anatergite greyish microtrichose. Mediotergite greyish microtrichose, but shining under scutellum. Scutellum microtrichose, with long apical setae and basal setulae.

Legs. Fore femur yellow, but darkened anteriorly; fore tibia yellow; foreleg tarsomeres 1-3 yellow, 4 and 
5 blackish. Mid and hind femora black, but yellow basally. Mid and hind tibiae black, but yellowish in apical quarter. Tarsomeres of mid- and hindlegs blackish. Fore femur and tibia as in Fig. 17. Mid coxa bare. Mid tibia without setae, except apical. Hind tibia with good visible osmeterium in basal half anterodorsally and with short preapical $d$.

Wing. Wing clear, only basal-costal cell darkened; veins brown. Calypters whitish; margin of upper calypter white, margin of lower calypter darkened. Halter yellowish. Alula entirely covered with microtrichia; width of alula approximately 2 times as long as the width of cell $\mathrm{bm}$.

Abdomen black, shining. Sternites 4 and 5 as in Fig. 18. Epandrium and surstyli as in Figs 19, 20.

Body length $4.2 \mathrm{~mm}$; wing length $3.5 \mathrm{~mm}$.

Female unknown.

COMPARISON. The new species is close to Meroplius cordylophorus Hennig, 1954 by structure of foreleg, but differing from it by the absence of seta on mid tibia (mid tibia of cordylophorus with $1 a v$ in apical third) and by the details of structure of male genitalia and by structure of male abdominal sternites 4 and 5 .

ETYMOLOGY. The specific epithet vikhrevi is named for my friend and colleague Nikita E. Vikhrev, who collected the type material of this and some other species included in this paper.

DISTRIBUTION. Ethiopia.

\section{Genus Sepsis Fallén, 1810}

Sepsis Fallén, 1810: 17. Gender: feminine. Type-species: Musca cynipsea Linnaeus, 1758, by designation of Curtis, 1829.

The largest genus of Sepsidae worldwide, with 42 recorded species in the Afrotropical Region. Afrotropical species are in need of revision and no key to species is currently available. Description of a new species from Ethiopia is given below.

\section{Sepsis amharaica Ozerov, sp.n.} Figs 21-24.

MATERIAL. Holotype $0^{7}$, ETHIOPIA: Amhara, Blue Nile $\left(10.08^{\circ} \mathrm{N} 38.19^{\circ} \mathrm{E}\right), 1070 \mathrm{~m}, 31 . \mathrm{VII} .2012$, col. N. Vikhrev (in ZMUM). Paratypes: same label as holotype $\left(20^{7} 0^{\top}, 1+\right.$, in ZMUM); ETHIOPIA: Amhara, Hayk L. (11.326 $\left.\mathrm{N} 39.688^{\circ} \mathrm{E}\right), 1950 \mathrm{~m}, 6-$ 7.VIII.2012, col. I. Gomyranov (10 1 1 , in ZMUM); ETHIOPIA: Amhara $\left(11.5397^{\circ} \mathrm{N} 39.608^{\circ} \mathrm{E}\right), 1950 \mathrm{~m}, 6 . \mathrm{VIII} .2012$, col. I. Gomyranov $\left(1+\right.$, in ZMUM); ETHIOPIA: Amhara, Jara R. $\left(11.381^{\circ} \mathrm{N}\right.$ $\left.39.642^{\circ} \mathrm{E}\right), 1650 \mathrm{~m}, 6$. VIII.2012, col. I. Gomyranov ( $1 \mathrm{O}^{7}$, in ZMUM); ETHIOPIA: Amhara $\left(11.539^{\circ} \mathrm{N} 39.639^{\circ} \mathrm{E}\right), 1990 \mathrm{~m}$, 6.VIII.2012, col. N. Vikhrev (1 $0^{7}$, in ZMUM).

DESCRIPTION. Length of body $2.8-4.6 \mathrm{~mm}$, length of wing 2.5-4.0 mm. Colour of body and legs vary from yellow to black, but fore tibia yellow, scutum in central part, anatergite, mediotergite and tergites 4 and 5 dorsally black.

Male. Head in lateral view slightly dorsoventrally flattened. Eye roundish. Frons subshining. Face, gena and postcranium microtrichose. Postpedicel in profile oval, slightly longer than wide. Arista bare. 1 ocellar, 1 postocellar, 1 inner vertical, 1 outer vertical setae present;
2 vibrissae. Occipital sclerite with several setulae.

Thorax microtrichose (dusted), but anepimeron in anterior half, pleural wing process, metepisternum along posterior margin and metepimeron completely shining. 1 postpronotal, 2 notopleural, $0+1$ supra-alar, 1 postalar, and 2 postsutural dorsocentral setae present. Anepisternum with seta near posterior margin. Postmetacoxal bridge absent. Scutellum with pair of well-developed apical setae and pair of basal setulae.

Legs. Coxa of foreleg simple. Foreleg as in Fig. 21. Mid coxa with a row of short hairs in upper half. Mid femur with $0-1 v$ at middle and 2-5 $a$ at middle, $1 \mathrm{ad}$ in apical third. Mid tibia with $1 v$ at middle, $2-4 p, 1$ preapical $d$ and apicals $a v$ and $v$. Hind femur with 2-3 $a d$ in apical third. Hind tibia with $1 d$ and 1-3 $a$ at middle and preapical $d$, and apical $a$; osmeterium or osmeterium-like area absent.

Wing normal, longer than abdomen, with small blackish spot at apex of $\mathrm{R}_{2+3}$; veins blackish. Cells $b m$ and $b r$ separate. Alula entirely covered with microtrichia, its width approximately 2.5-3.0 times as long as the width of cell $\mathrm{bm}$. Calypteres and margins whitish or yellowish. Margin of upper calypter with hairs, margin of lower calypter without hairs. Halter whitish or yellowish.

Abdomen matt, strong constricted after syntergite $1+2$, the latter at sides with several setae. Tergites 3-5 with several marginal setae. Sternites 4 and 5 as in Fig. 22. Surstyli symmetrical (Figs 23, 24).

FEMALE. Resembles male. Foreleg simple. Mid femur with $1 a$ in apical third. Hind femur with 2-3 ad in apical third. Hind tibia with $1 \mathrm{ad}$ at middle, 1 preapical $d$, and apical $a$.

COMPARISON. The new species is more similar to Sepsis fissa Becker, 1903, Sepsis femoriseta Duda, 1926, and Sepsis petulantis Adams, 1905, but can easily be recognised by the structure of fore leg and genitalia.

DISTRIBUTION. Ethiopia: Amhara Prov.

ACKNOWLEDGEMENT. The author would like to thank Dr. Adrian Pont (London) for very importan information about the holotype of A. aethiopica.

\section{References}

Cumming J.M., Wood D.M. 2009. Adult morphology and terminology // Brown B.V., Borkent A., Cumming J.M., Wood D.M., Woodley N.E., Zumbado M. (eds.). Manual of Central American Diptera. Vol. 1. National Research Council Press, Ottawa. P.9-50.

Fallén C.F. 1810. Specimen entomologicum novam Diptera disponendi methodum exhibens. Lundae [= Lund]. 26 pp.

McAlpine J. F. 1981. Morphology and terminology-adults // McAlpine J.F., Peterson B.V., Shewell G.E, Teskey H.J., Vokeroth J.R., Wood D.M., Coordinators. Manual of Nearctic Diptera. Volume 2. Research Branch, Agriculture Canada. Monograph 27. Ottawa. P.9-63.

Ozerov A.L. 1996. To the fauna and taxonomy of African Sepsidae (Diptera) // Russian Entomological Journal. Vol.4 (for 1995). No.1-4. P.127-144.

Ozerov A.L. 1999a. Studies of Afrotropical Sepsidae (Diptera). I. A revision of the genus Afrosepsis Ozerov // International Journal of Dipterological Research. Vol.10. No.1. P.59-66. 

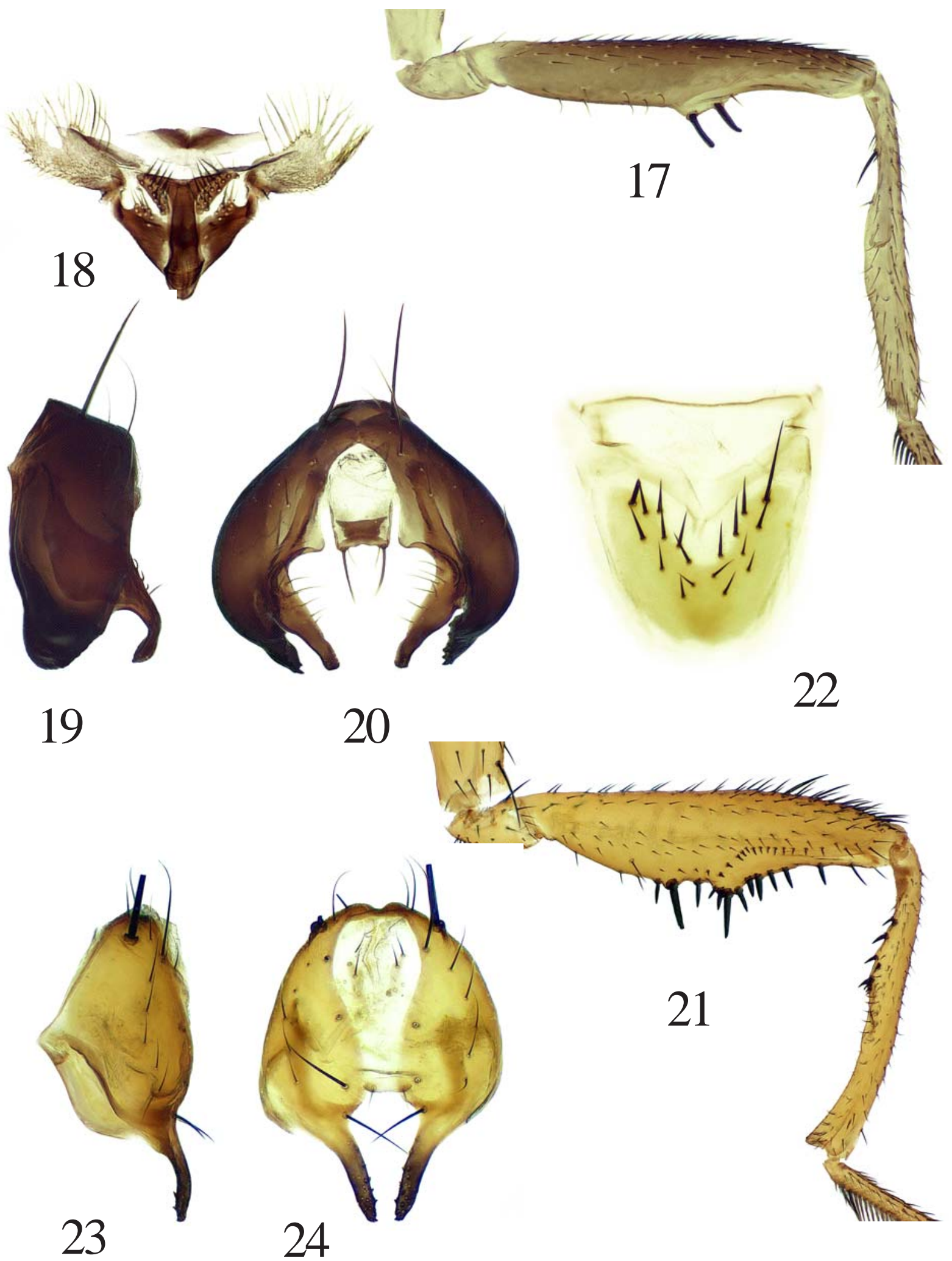

Figs 17-24. Meroplius vikhrevi Ozerov, sp.n. (17-20) and Sepsis amharaica Ozerov, sp.n. (21-24), O': 17, 21 - fore left leg, anterior view; 18, 22 - sternites 4 and 5; 19, 23 - epandrium, cerci and surstyli, lateral view; 20, 24 - epandrium, cerci and surstyli, dorsal view.

Рис. 17-24. Meroplius vikhrevi Ozerov, sp.n. (17-20) and Sepsis amharaica Ozerov, sp.n. (21-24), о : 17, 21 — передняя левая нога, спереди; 18, 22 - стерниты 4 и 5; 19, 23 - эпандрий, церки и сурстили, сбоку; 20, 24 - эпандрий, церки и сурстили, сверху. 
Ozerov A.L. 1999b. Studies of Afrotropical Sepsidae (Diptera). II A revision of the genus Meroplius Rondani // International Journal of Dipterological Research. Vol.10. No.2. P.81-96.

Ozerov A.L. 2000. Studies of afrotropical Sepsidae (Diptera). III. A revision of the genus Adriapontia Ozerov // Russian Entomological Journal. Vol.8 (for 1999). No.4. P.269-278.

Ozerov A.L. 2004. New genera and species of Sepsidae (Diptera) // Russian Entomological Journal. Vol.12 (for 2003). No.4 P.399-420.

Ozerov A.L. 2005. World Catalogue of the family Sepsidae (Insecta: Diptera) // Zoologicheskie Issledovania. Vol.8. 74 pp.

Ozerov A.L. 2006. Studies of Afrotropical Sepsidae (Diptera). V. Key and diagnoses of genera of Afrotropical Sepsidae // Russian Entomological Journal. Vol.15. No.1. P.93-108.
Ozerov A.L. 2010. Three new species of Sepsidae (Diptera) // Far Eastern Entomologist. No.209. P.1-6.

Ozerov A.L. 2011. A new species of Meroplius Rondani (Diptera, Sepsidae) from Zambia // Far Eastern Entomologist. No.229. P.11-12.

Rondani C. 1874. Species italicae ordinis Dipterorum (Muscaria Rndn.). Stirps XXI. - Tanipezinae Rndn. Collectae et observatae // Bollettino della Societa Entomologica Italiana. Vol.6. P.167-182.

Stuckenberg B.R. 1999. Antennal evolution in the Brachycera (Diptera), with a reassessment of terminology relating to the flagellum // Studia Dipterologica. Vol.6. S.33-48. 